\title{
INFORMATION SUPPLY ISSUES IN TOURIST TRANSPORT IN NIGERIA: ROLE FOR LOGISTICS AND INFORMATION TECHNOLOGY
}

\author{
*UKABUILU, EMMANUEL N. AND **ENEMUO, OGECHI B. \\ * Department of Hospitality and Tourism Management \\ Imo State University, Owerri \\ ** Department of Home Economics/Hotel Management and Tourism \\ Michael Okpara University of Agriculture, Umudike.
}

\begin{abstract}
This paper examines the role of logistics and information technology in tourists systems in Nigeria. Data used were collected through questionnaire. A structured questionnaire was administered to 30 randomly selected respondents at the Port Harcourt International Airport. Data were analysed using descriptive statistics. The findings reveal the various roles of information technology and logistics in tourists transport as being very vital to increasing customers' satisfaction, patronage and also having good competitive advantage over others. It important that for any tourist transport organization to be in the business, there should be good information technology, adequate logistic procedure and other important condition that would improve the tourist satisfaction.
\end{abstract}

Key words: Information technology, tourist, transportation, logistics.

\section{INTRODUCTION}

The increasing rate of growth and development in the world today, has led to the increase in the use of information technology. According to Poon (1988) Information Technology (IT) is the collective term given to the most recent development in the mode (electronic) and the mechanisms(computer and communications technologies as well as the software which drive them) used for the acquisition, processing, analysis, storage, retrieval, dissemination and application of information" Information technology is permeating the entire tourism industry. Tourism comprises the activities of persons traveling to the and stay in places outside their usual environment for not more than one consecutive year for leisure, business and other purposes not related to the exercise of an activity remunerated from within the place visited (WTO 2004) Tourism is an ever expanding smokeless service industry with latent vast growth potential and has therefore become one of the pivotal concerns of not only the nations but international community as a whole; tourism owes its outset to the onset of the transport revolution (Sheela 2005)

Information technology is very useful in tourism industry because of tourism's dependence upon the supply and exchange of information throughout the production distribution chain. Information can largely be understood as constituting the tourism product since it is characteristically intangible, perishable, volatile and heterogeneous; consequently, information assumes a vitally important role which in turn generate a need for information technology (Bennett and Radburn 1993).According to Poon (1988) there is not just one type of information technology but a whole system of information technologies. Airlines use IT not just for schedule displays but for flight planning, departure control ,catering, crew management and cargo control.

It is also pertinent to note that the immediate impact of tourists transport providers to up-to date information flow which is very crucial when supply chain exists and the transport provider is just one component of the overall tourist system. Ukabuilu (2006:32) observed also that the customers' service explosion mean there is need for consistent provision of time 
and place utility. In other words products do not have value until they are in the hands of customers at the time and place required.

Logistics of services delivery are of paramount importance and enables management add value and deliver a consistent product (Page 2005:257). Hence, this logistics is the process which seeks to provide management and coordination of all activities within the supply chain of sources and acquisition, through production, where appropriate and through distribution channels to the customers (Quayle 1993:9). Logistics provides a competitive advantage by offering strategic view of operational issues and an understanding of the links in the supply system. It also assists in the coordination of services delivery function and transport in its own way is a vital element of logistics in moving the customer nearer to the product in a tourism context "logistics performs a vital role in providing the link between market place and operating activities" (Caves and Gosling 1999:32)

Sheldon (1997:19) observed that model of tourism information flows, consist of three main agents: Travelers, suppliers and the travel intermediaries. It is pertinent to understand that it is the supplier that make as use if IT to handle, utilize and manage these information flows that is of interest and this information is essential to allow the organization to function and different department to make decision about corporate objectives, their consumers and competitors. Poon (1993) observed that airline industry make use of IT in the following: Global Distribution system (GDS), Frequent flyers database, Yield management programme, Distribution and marketing of their products, The design, operation and maintenance of craft and luggage handling, Check-in-system at airport.

Other transport sectors involved in tourism that also make use of IT are train operators, car rental agencies, and coach and cruise ship operators. It is probably most highly developed in airline sector due to the huge amount of capital involved in the investment.

The diagram below shows the various logistics mix.

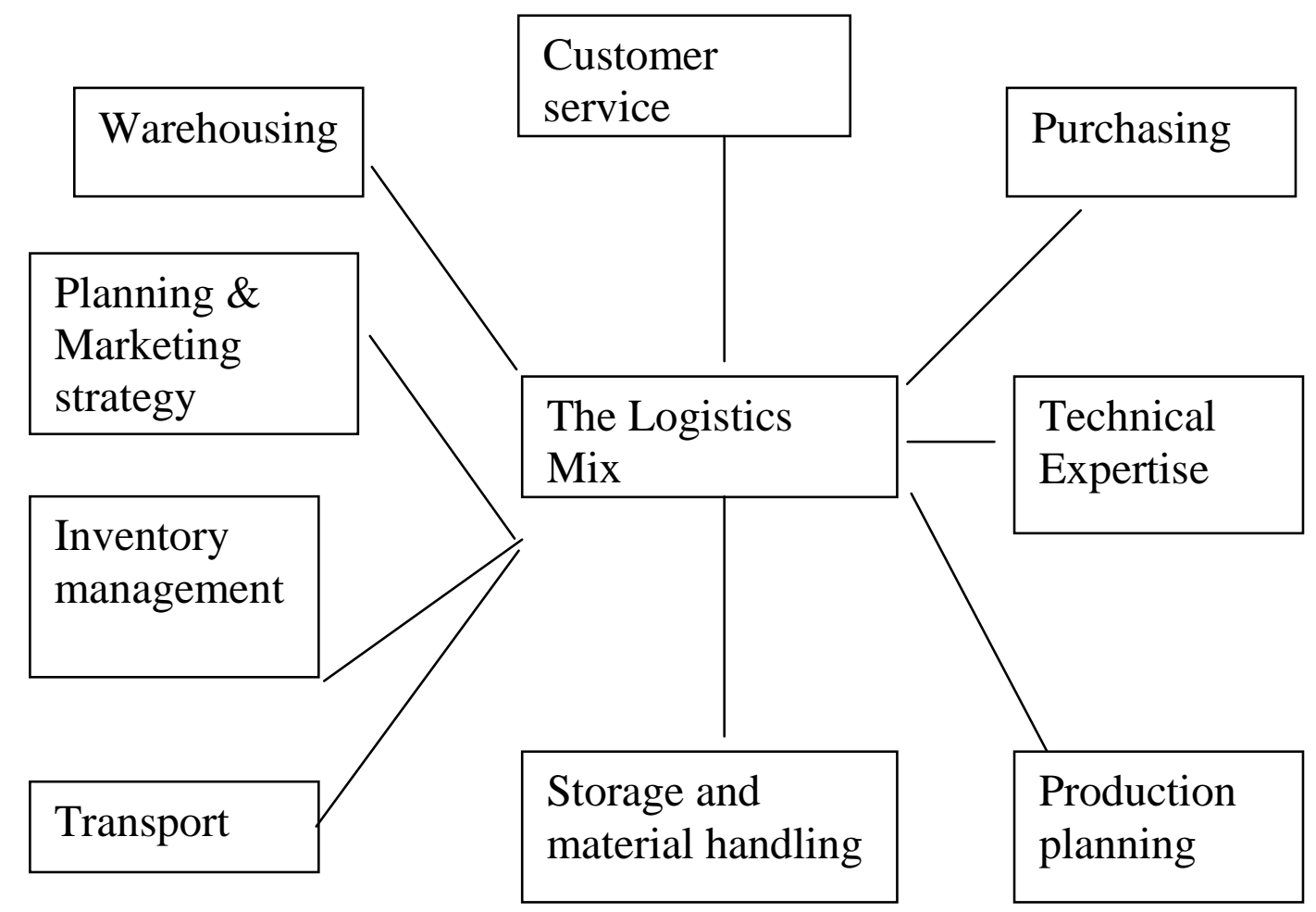

Fig 1: The scope of logistics (Page 2005:251) 
Sheldon (1997) also traces the development of CRSs into Global Distribution System (GDS) as CRS that are affiliated with airlines. These GDs have the following advantages in showing data in multiple carriers, as noted by Page (2005:253): Flight schedule and availability; Passenger information; Fare quotes and rules for travel; Ticketing

Sheldon (1997:27), Wilkinson (1987:22), Evans (2003:32) also identify the use of global distribution systems. Airlines have also established presence on the internet and are using it as an important distribution channel especially to customers through use of credit cards.

This study will no doubt help the management of most tourists transport to figure out how to package information to customers in a way that will make them gain competitive advantage over other organizations. It will help management to improve on their services and reduce time, cost and ensure efficiency. It will also help to ascertain the areas where they need improvement and finally it states advantages of IT to both organizations and customers.

The purpose of this study is to ascertain:

- The role of information technology in improving the services of customers via increasing patronages.

- The role of (ICTs) logistics in tourists transport organizations to have good competitive advantage over their counterparts

\section{METHODOLOGY}

The sample size of the study consists of 30 staff which was randomly selected from Port Harcourt International Airport, Omagwa. Questionnaire was used as the instrument for data collection. The questionnaire was structured based ion the factors identified in the literature review and were structure in a five point likert from: strongly agreed (5), Agreed (4), Undecided (3), Disagreed (2) and strongly disagreed (1) was used to elicit information from respondents. The instrument was administered on respondents and a total of 28 copies were duly filled and returned. These 28 copies where analyzed. The decision line was 3.0. This means that decision with 3.0 and above is those which the respondents agree/perceived as important.

\section{Research Questions 1}

Finding of the research question 1 are summarized in table 1

Table 1: Mean Rating by staff in determining areas where information technology helps in improving customers' satisfaction and increasing patronage.

\begin{tabular}{|c|c|c|c|c|}
\hline $\mathbf{S} / \mathbf{N}$ & Areas where IT helps & Mean & Remarks & $\begin{array}{l}\text { Not } \\
\text { important }\end{array}$ \\
\hline 1 & $\begin{array}{l}\text { Helps in baggage \& cargo } \\
\text { handling system }\end{array}$ & 4.3 & Importance & \\
\hline 2 & $\begin{array}{l}\text { Cabin automaton (Entertainment } \\
\text { visual rolite }\end{array}$ & 4.4 & “ & \\
\hline 3 & Safety system & 4.4 & “ & \\
\hline 4 & Decision support system & 4.0 & “ & \\
\hline 5 & $\begin{array}{l}\text { Flight scheduling } \\
\text { management }\end{array}$ & 4.3 & “ & \\
\hline 6 & Crew scheduling \& management & 4.1 & “6 & \\
\hline 7 & Gate management and control & 4.1 & ، & \\
\hline
\end{tabular}

Table 1 showed that all the 9 areas were helped by IT 
Table 2: Finding of the research question 2 are summarized in table 2: Determining the role of logistics

\begin{tabular}{|c|c|c|c|}
\hline $\mathbf{S} / \mathbf{N}$ & Areas were proper logistics helps in tourist transport & Mean & Agreed \\
\hline 1 & Cost reduction and management & 3.8 & Agreed \\
\hline 2 & Product differentiation advantage of competitors & 3.9 & Agreed \\
\hline 3 & Segmentation and targeting & 3.5 & Agreed \\
\hline 4 & Speedy reactions & 4.4 & Agreed \\
\hline 5 & Marketing research & 4.4 & Agreed \\
\hline 6 & Innovations & 4.2 & Agreed \\
\hline 7 & Promotes growth & 3.9 & Agreed \\
\hline 8 & Out source non-core business to pertness & 3.86 & Agreed \\
\hline 9 & Standardization of quality control system & 3.9 & Agreed \\
\hline 10 & Integration all internal and external process & 3.8 & Agreed \\
\hline 11 & Provide incentive to create loyalty & 3.3 & Agreed \\
\hline 12 & $\begin{array}{l}\text { Helps to avoid substitution and barrier to entry (fight } \\
\text { competition) }\end{array}$ & 4.4 & Agreed \\
\hline 13 & Provide timely solutions to customers and trade problems & 4.6 & Agreed \\
\hline 14 & Maximize interaction and reduce response time & 3.0 & Agreed \\
\hline 15 & Increase criminal acts & 2.0 & disagreed \\
\hline
\end{tabular}

Table 2 shows that among the 15 points materials analyzed above, 14 of them are relevant areas where logistics helps in tourists transport The point that has the highest mean rating of 4.6 is provide timely solution to customers and trade problems. Other points with mean rating of 4.4 are speedy reaction, marketing research and help to substitution and barrier to entry (fight competition).Other point that have mean rating of 4.2 is innovations .Product differentiation advantage of competitors, promotes growth and standardization of quality control system are the next with mean rating of 3.9 each. Cost reduction and management, out source non-core business to pertness and integration of all internal and external process have the rating of 3.8 each. Segmentation and targeting has the mean of 3.5.Provide incentive to create loyalty has the mean of 3.3.Maximize interaction and reduce response time has the mean rating of 3.0.

\section{DISCUSSION}

The findings of table1 above reveal the areas where the information technology helps in tourists' transportation through customers' satisfaction and increasing patronage. The items in the table 1 showed the areas where information technology helps in customer's satisfaction via increasing their patronages. Some of then are also in accordance with what Zinyama (1989:62-65), Whitelegg (1987:91), Wheatcoft (1994:95), and Turto (1999:92) stated as some of the roles of IT to improve customers satisfaction and patronage.

The findings from table 2 shows that the role of logistics towards helping the tourist transport organization to have good competitive advantage above others. It showed fourteen areas where it will help the airport tourist transport business to have advantage but rejected the idea of increasing criminal acts of the organizations. This was shown on table 2 (from nos 1-14). Those points also conform to some of the points mentioned by Thornberry and Hennessy (1992:19). Sustrans (2002:16), Peisley (2000:31) and Dogani (1992:33) that logistics aid tourist transport organizations to have competitive advantage over others.

\section{CONCLUSION AND RECOMMENDATIONS}

It is concluded that Information technology improves customer's service satisfaction which invariably helps in improving customer's patronage. Logistics makes the organization 
to have competitive advantage over others which invariably makes them to have high patronage and to continuously be in business. It is recommended that for any tourist transport organizations to be in business, the following points must be considered:

- The establishment should have good information technology

- They should have adequate logistics procedures

- Ensure that effort is made in information technology regarding safety system, flight scheduling, bagging handling, gate managements and control, decision support system and trustworthy personnel's.

- Experts must be employed to avoid fraud or defrauding the organization.

- Adequate logistics must be put in place more especially in cost reduction, speedy reaction, innovation, and growth promotion, integration of internal factors and external factors, and timely solutions to promotions or services.

- Logistics on how to maintain quality products and services should not be overlooked.

- Logistics for proper marketing segmentation and research and speedy reactions should not be overlooked in tourist transport.

\section{REFERENCES}

Caves R. and Gosling, D (1999) Strategic Airport Planning. Oxford: Pergamon

Doganis R. (1991) Flying off course: The Economics of International Airlines. London: Routledge.

Evans N, Campbell, D and Stonehouse G (1992) Strategic Management for Travel and Tourism, Oxford: Butterworth. Heinemann.

Hepworth, M. and Ducatel K. (1992) Transport in the information Age: Wheels and Wires, London: Belhanen

Page, S.J. (2004) Air Travel in Asia, travel and Tourism Analyst 3:1-56

Page S.J (2005) Transport and tourism $2^{\text {nd }}$ edition. London: Pearson.

Peisley T (2000) "Cruising in Crisis" Travel and Tourism Analyst, 2, 1-39

Poon A. (1989) "Competitive Strategies for a new Tourism in C.P. Cooper (edn) Progress in Tourism. Recreation and Hospitality management Vol 4 London Belhaven 21-102

Poon, A. (1988) Tourism and Information Technology. Annal Tourism Research.vol 15 Quayle, M (1993) Logistics: An Integrated Approach, Kent: Holdder \& Stoughton.

Sheldon, P. (1997) Tourism Information Technology. Wallingford: CAB International.

Sustran S (2002) National Cycle Network. Route usage monitoring programme. Bristol: Sustran

Sheel, A. M (2005) Economics of Hotel Management. New Delhi, New Age International Publishers LTD

Sinclair, M. T and Stabler, M. J (1993) The Tourism Industry :An International Analysis,UK $\mathrm{CAB}$ international pub.

Thornberry, N and Hennessey N (1992) Customer care, Much More than a Smile: developin a Customer Service Infrastructure; European management Journal 10(4): 400-408

Turton, B (1991) "The Changing Transport Pattern" in R.J. Johnstron and V. Gardiner (eds) The Changing Geography of British Isle edn, London Routledge.

Ukabuilu, E. Introduction to Tourism management: Aba Ugoeze

Wheatforts S. (1994) Aviation and Tourism Policies. London Routledge/World Tourism Organization.

Whitelegg, J (1987) "Rural Railways and Disinvestment in rural areas" Regional studies 21 (1) $54-56$

Zinyama L. (1989) “Some Recent Trends in Tourist Arrivals in Zimbabwe, 74(1): 62-65 